\title{
Antiphospholipid syndrome and neurofibromatosis type I: a coincidence or new association?
}

\author{
Síndrome antifosfolípide e neurofibromatose tipo I: uma coincidência \\ ou nova associação?
}

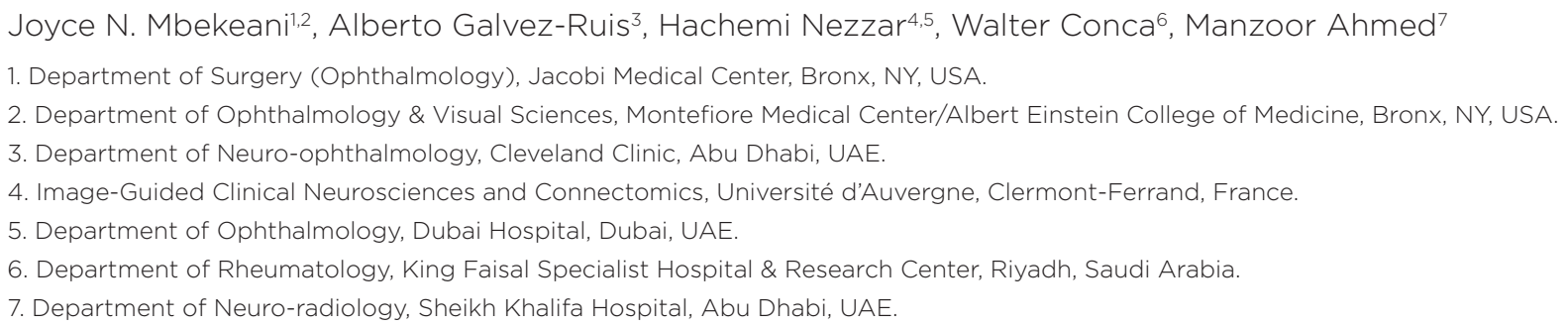

\begin{abstract}
I Numerous studies have reported on structural vascular anomalies and ischemia associated with neurofibromatosis type 1 that are thought to stem from dysfunction of neurofibromin, the neurofibromatosis type 1 protein. Documented cases of associated antiphospholipid syndrome fulfilling the accepted diagnostic criteria are exceptionally rare, with only three cases reported in the literature. Here, we report on a patient with neurofibromatosis type 1 and a history of spontaneous abortions presenting with sudden vision loss in the right eye and swelling of the optic nerve head. Fluorescein angiography indicated anterior ischemic optic neuropathy. Brain magnetic resonance imaging revealed findings consistent with left cavernous sinus meningioma. Serologic testing demonstrated persistently elevated anti- $\beta_{2}$-glycoprotein antibodies. Her findings suggested antiphospholipid syndrome with concomitant clinical and laboratory evidence of antiphospholipid syndrome: frequent abortions, a vaso-occlusive episode, and persistently elevated antiphospholipid syndrome antibodies. To our knowledge, this case represents the first neuro-ophthalmic manifestation of antiphospholipid syndrome associated with neurofibromatosis type 1 .
\end{abstract}

Keywords: Neurofibromatosis type 1; NF1; Antiphospholipid syndrome; Fluorescein angiography; Case report

Submitted for publication: August 27, 2018

Accepted for publication: November 15, 2018

Funding: No specific financial support was available for this study.

Disclosure of potential conflicts of interest: None of the authors have any potential conflicts of interest to disclose.

Corresponding author: Joyce N. Mbekeani.

Dept. of Surgery (Ophthalmology), Jacobi Medical Center, 1400 Pelham Parkway, Bronx, NY 10461 USA - E-mail: jnanjinga888@gmail.com
RESUMO | Inúmeros estudos têm relatado anomalias vasculares estruturais e isquemia associada com à neurofibromatose tipo 1 que, acredita-se, resultam da disfunção da neurofibromina, a proteína tipo 1 da neurofibromatose. Casos documentados de síndrome antifosfolípide associada que atendem aos critérios diagnósticos aceitos são excepcionalmente raros, com apenas três casos relatados na literatura. Aqui, relatamos um paciente com neurofibromatose tipo 1 e histórico de abortos espontâneos apresentando perda repentina de visão no olho direito e edema de cabeça do nervo óptico. A angiofluoresceínografia indicou neuropatia óptica isquêmica anterior. Ressonância magnética cerebral revelou achados compatíveis com meningioma do seio cavernoso esquerdo. O teste sorológico demonstrou anticorpos anti- $\beta_{2}$ glicoproteína persistentemente elevados. Seus achados sugerem síndrome antifosfolípide com evidências clínicas e laboratoriais concomitantes de síndrome antifosfolipídica: abortos frequentes, episódio vaso-oclusivo e anticorpos antifosfolípides persistentemente elevados. Pelo nosso conhecimento, este caso pode representar a primeira manifestação neuro-oftálmica da síndrome antifosfolípide associada à neurofibromatose tipo 1 .

Descritores: Neurofibromatose tipo 1; NF1; Síndrome antifosfolipídica; Angiofluoresceinografia; Relato de caso

\section{INTRODUCTION}

Manifestations of neurofibromatosis type 1 (NF1), a common autosomal dominant disorder, result from the mutation of a large gene on chromosome 17 that encodes for the protein neurofibromin. Sharing structure and functional homology with RAS GTPase-activating proteins, it downregulates the mitogenic effects of RAS oncogenes and thus functions as a tumor suppressor gene $^{(1)}$. The full spectrum of neurofibromin functions 
has yet to be clarified but might also include growth, learning, and wound healing. Structural vascular anomalies and NF1-associated ischemia are thought to result from aberrant neurofibromin dysfunction. Although this protein is expressed in the myocardium, endocardium, and vascular endothelial and smooth muscle cells, the exact pathogenesis leading to the various vasculopathies remains obscure and may include hyperproliferation of Schwann cell, pericytes and endothelial cells, altered constitution and function of cellular components of vessel walls, and anomalous maintenance and repair(1-3). Here, we present a case of NF1 and non-arteritic optic neuropathy associated with immune dysregulation, a possible contributor to focal vascular disruption.

\section{CASE REPORT}

A previously healthy 40 -year-old woman with a history of asymptomatic NF1 presented with sudden, painless vision loss in the right eye. She had pale disk edema, scattered peripapillary flame hemorrhages, cotton wool spots, and dilated tortuous veins in the affected eye. Fundus fluorescein angiogram of the right eye exhibited temporal choroidal filling and disc perfusion delay at 19 $\mathrm{s}$ and a gradual increase in papillary leakage from $34 \mathrm{~s}$ to 4 min post-injection. The likely diagnosis was non-arteritic anterior ischemic optic neuropathy with venous insufficiency. T1-weighted magnetic resonance imaging of the brain revealed an enhancing left cavernous sinus lesion encasing a normal caliber cavernous internal carotid artery consistent with meningioma. Trigeminal nerve schwannoma may exhibit similar features.

The patient was examined by a neuro-ophthalmologist as part of her pre-radiation workup. Her history was significant for three spontaneous abortions in the first trimester. Two of her three children also had NF1 with dermatologic stigmata including café au lait spots, axillary freckles, and skin fibromas. Visual acuities of $20 / 300$ in the right eye and 20/25 in the left eye were revealed on examination. Extraocular movements were intact, and Ishihara color vision test results were 1/15 and 15/15 in the right and left eyes, respectively. Her pupils were round and reactive with right relative afferent pupillary defect. The anterior segments were remarkable for a left iris Lisch nodule. Ophthalmoscopy presented optic atrophy and attenuated sheathed peripapillary vessels in the right eye but no retinal collaterals or neovascularization. The left optic nerve was pink but crowded without a cup or "disc at risk." Optical coherence tomography of both optic nerves demonstrated right nerve atrophy with reduced retinal nerve fiber layer (RNFL) thickness of $52 \mu \mathrm{m}$. The left optic nerve was small, with an RNFL of $97 \mu \mathrm{m}$.

General physical and neurologic examinations were unremarkable except for the presence of multiple café au lait spots. The left cavernous lesion was clinically silent. The patient had no known predisposing factors for the apparent vaso-occlusive event; therefore, serologic tests were performed, revealing significant elevations of the erythrocyte sedimentation rate (ESR) of $51 \mathrm{~mm} / \mathrm{h}$ (normal $0-29 \mathrm{~mm} / \mathrm{h}$ ), anti- $\beta 2$-glycoprotein $1 \lg A$ of $19.2 \mathrm{U} / \mathrm{mL}$, and anti- $\beta 2$-glycoprotein $1 \operatorname{lgM}$ of $12.1 \mathrm{U} / \mathrm{mL}$ (negative $<10.0 \mathrm{U} / \mathrm{mL}$ ). After 12 weeks, repeat serology showed persistently elevated ESR of $37 \mathrm{~mm} / \mathrm{h}$ and anti- $\beta 2$-glycoprotein $1 \mathrm{lgA}$ of $13.8 \mathrm{U} / \mathrm{mL}$. Antinuclear and double-stranded DNA antibodies were within normal limits. On the basis of a right non-arteritic anterior ischemic optic neuropathy (NAION), history of spontaneous abortions, and continuously elevated anti$\beta 2$-glycoprotein 1 IgA, we made a diagnosis of antiphospholipid syndrome (APS) and referred her to Rheumatology for further workup to rule out other autoimmune disorders and to prevent further thromboembolic events.

\section{DISCUSSION}

An association of NF1 and APS, a prothrombotic autoimmune disease, is unusually rare. Very few documented cases fulfill the accepted criteria for a diagnosis of APS (Table 1) ${ }^{(4-6)}$. The currently accepted criteria for defining APS are the presence of at least one clinical criterion: $\geq 1$ thromboembolic episodes and/or pregnancy morbidity or spontaneous fetal loss and at least one laboratory criterion: presence of lupus anticoagulant (LA), anticardiolipin antibody or anti- $\beta_{2}$-glycoprotein 1 (IgG and $\operatorname{lgM}$ ) on two occasions separated by 12 weeks. Dilute Russell's viper venom time and activated partial thromboplastin time may be used instead of LA. The clinical and laboratory evidence should coincide within 5 years. Our patient had NAION with associated venous insufficiency, a significant history of pregnancy morbidity, and anti- $\beta_{2}$-glycoprotein 1 lgA. Although $\lg A$ autoantibodies are not included in the current Sydney Classification Criteria ${ }^{(8)}$ for diagnosing APS, the associated clinical picture is presumably pathologic.

Hayreh $^{(7)}$ reported on predisposing factors leading to NAION and found that a combination of systemic and local factors variably contribute to the compromised posterior ciliary artery blood supply in anterior optic nerve ischemia. He stressed that NAION was mainly a hypotensive disorder and rarely thromboembolic in nature. However, antiphospholipid autoantibodies have been 
Table 1. Summary of reported cases of concomitant neurofibromatosis type I and antiphospholipid syndrome

\begin{tabular}{|c|c|c|c|c|c|c|}
\hline Report & Age/sex & NF1 diagnosis & History & Vascular event & Workup & Positive antibodies \\
\hline Carr et al, $1989^{(4)}$ & $35 / F$ & $\begin{array}{l}\text { Multiple Excision/ } \\
\text { Biopsies of fibroma } \\
\text { (childhood) }\end{array}$ & $\begin{array}{l}2 \text { miscarriages and } 2 \\
\text { stillbirths } \\
\text { Chronic headaches }\end{array}$ & $\begin{array}{c}\text { Left facial weakness and } \\
\text { hand "clumsiness" } \rightarrow \text { Right } \\
\text { CVA }\end{array}$ & $\begin{array}{l}\text { CT/MRI brain: Right } \\
\text { corona radiate and } \\
\text { parietal lobe infracts } \\
\text { and right optic nerve } \\
\text { thickening } \\
\text { Cerebral } \\
\text { angiography: paucity } \\
\text { of sylvian vessels } \\
\text { (Details of } \\
\text { ophthalmic workup } \\
\text { not documented) }\end{array}$ & ANAIgG aCLIgM aCL \\
\hline $\begin{array}{l}\text { Xavier de Freitas et al, } \\
2010^{(5)}\end{array}$ & $28 / F$ & $\begin{array}{l}\text { Excision/Biopsy in } \\
\text { adolescence }\end{array}$ & $\begin{array}{l}\text { Pre-eclampsia and } \\
\text { miscarriage }\end{array}$ & $\begin{array}{l}\text { Hemiparesis \& dysarthria } \\
\rightarrow \text { CVA } \\
\text { Myocardial infarction X2 }\end{array}$ & $\begin{array}{l}\text { Neuroimaging and } \\
\text { cardiovascular } \\
\text { investigations not } \\
\text { documented }\end{array}$ & $\operatorname{lgG} \mathrm{aCL}$ \\
\hline Finsterer et al, $2013^{(6)}$ & $38 / \mathrm{F}$ & $\begin{array}{l}\text { Café au lait spots } \\
\text { Limb \& lumbar } \\
\text { fibromaOptic nerve } \\
\text { glioma } \\
\text { (+) Family history }\end{array}$ & $\begin{array}{c}2 \text { miscarriages } \\
\text { Migraines/tension } \\
\text { headaches } \\
\text { Cervical } \\
\text { cancerHyperlipidemia } \\
\text { Smoker/OCP } \\
\text { useSplenomegaly \& } \\
\text { Thrombocytopenia }\end{array}$ & $\begin{array}{c}\text { Chest pain and dyspnea } \rightarrow \\
\text { Myocardial infarction } \\
\text { Diplopia, left vision loss, } \\
\text { dyschromatopsia and } \\
\text { photopsia }\end{array}$ & $\begin{array}{l}\text { Elevated troponin } \\
\text { ECG and coronary } \\
\text { angiography: stenosis } \\
\text { in both right and left } \\
\text { tributaries } \\
\text { MRI: right parietal } \\
\text { gliosis } \\
\text { (Details of } \\
\text { ophthalmic workup } \\
\text { not documented) }\end{array}$ & LACDRVVT \\
\hline $\begin{array}{l}\text { Mbekeani et al, } 2018 \\
\text { (this report) }\end{array}$ & $38 / F$ & $\begin{array}{l}\text { Café au lait spots } \\
\text { Lisch nodule } \\
\text { Molecular genetics(+) } \\
\text { Family history }\end{array}$ & 3 miscarriages & $\begin{array}{c}\text { Sudden painless right vision } \\
\text { loss } \rightarrow \text { right NAION with } \\
\text { venous congestion }\end{array}$ & $\begin{array}{c}\text { FFA (initial): right } \\
\text { NAION } \\
\text { OCT (subsequent): } \\
\text { optic nerve atrophy } \\
\text { MRI: left cavernous } \\
\text { meningioma; no } \\
\text { ischemia }\end{array}$ & $\begin{array}{c}\text { Anti- } \beta 2 \text { glycoprotein } 1 \\
\text { lgAAnti- } \beta 2 \text { glycoprotein } \\
1 \text { lgM }\end{array}$ \\
\hline
\end{tabular}

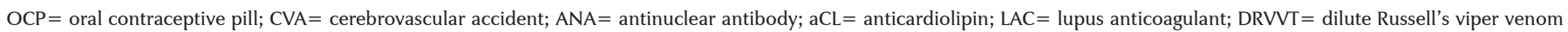
time; FFA = fundus fluorescein angiography; OCT = optical coherence tomography

demonstrated in cases of NAION and probably contribute to optic nerve ischemia by causing a prothrombotic shift $^{(8)}$. The presence of antiphospholipid autoantibodies alone rarely leads to vaso-occlusion, and the mechanism in our patient was likely multifactorial, requiring a combination of thrombophilia, crowded optic nerve head, and altered neurofibromin-related microvasculopathy of the posterior ciliary artery.

A variety of retinal vascular occlusion disorders affiliated with NF1 have been reported ${ }^{(9)}$ and presumably result from microvascular disruption secondary to mutation of NF1. It is not yet known whether antiphospholipid autoantibodies play a role in these vasculopathies. Although an association of NF1 and APS has been reported, to our knowledge, this case documents the first neuro-ophthalmic manifestation of APS associated with NF1. The concurrence of these disorders, both with wide phenotypic spectra, might be coincidental but could represent an unrecognized association. Therefore, we recommend considering APS in cases of ocular ischemia in patients with NF1 who lack predisposing factors and investigating these patients accordingly.

\section{REFERENCES}

1. Oderich GS, Sullivan TM, Bower TC, Gloviczki P, Miller DV, Babovic-Vuksanovic D, et al. Vascular abnormalities in patients with neurofibromatosis syndrome type l: clinical spectrum, management, and results. J Vasc Surg. 2007;46(3):475-84. Comment in: J Vasc Surg. 2008;47(6):1378-9.

2. Salyer WR, Salyer, DC. The vascular lesions of neurofibromatosis. Angiology. 1974;25(8):510-9.

3. Ozerdem U. Targeting neovascular pericytes in neurofibromatosis type 1. Angiogenesis. 2004;7(4):307-11.

4. Carr ME Jr, Howe CW. Lupus anticoagulant and cerebrovascular accident in a patient with neurofibromatosis. South Med J. 1989; 82(7):921-3.

5. Xavier de Freitas CZ, Bisi MC, Sinnott Silva, L, Bodanese LC, Staub HL. Neurofibromatosis type I and antiphospholipid syndrome. Rev Med Chile. 2010;138(12):1562.

6. Finsterer J, Stöllberger C, Schäffl-Doweik L. Neurofibromatosis type $\mathrm{I}$ and anti-phospholipid antibody syndrome. Report of one case. Rev Méd Chile. 2013;141(8):1068-71.

7. Hayreh SS. Ischemic optic neuropathies - where are we now? Graefes Arch Clin Exp Ophthalmol. 2013;251(8):1873-84.

8. Watts MT, Greaves M, Rennie IG, Clearkin LG. Antiphospholipid antibodies in the aetiology of ischaemic optic neuropathy. Eye (Lond). 1991;5(Pt 1):75-9.

9. Karadimas $\mathrm{Pl}$, Hatzispasou E, Bouzas EA. Retinal vascular abnormalities in neurofibromatosis type 1. J Neuroophthalmol. 2003; 23(4):274-5. 